\title{
Community intervention in the Nursing education: experience report
}

\author{
Intervenção comunitária na educação em enfermagem: relato de experiência \\ Intervención comunitaria en la educación en enfermería: relato de experiencia
}

\section{Elsy Alejandra de Oliveira Tavares', Maria Teresa de Sousa Frango Pinheiro', Helena Maria Guerreiro José' \\ 'Instituto Superior Politécnico de Saúde Multiperfil. Luanda, Angola.}

\begin{abstract}
How to cite this article:
Tavares EAO, Pinheiro MTSF, José HMG. Community intervention in the Nursing education: experience report. Rev Bras Enferm [Internet]. 2018;71(Suppl 4):1774-8. [Thematic Issue: Education and teaching in Nursing]

DOI: http://dx.doi.org/10.1590/0034-7167-2017-0351
\end{abstract}

\author{
Submission: 05-17-2017 Approval: 07-07-2017
}

\section{ABSTRACT}

Objective: To report the implementation and results of community intervention projects used as a strategy for teaching and developing people and communities in the training of community health nursing specialists at the Centro de Formação de Saúde Multiperfil (Multi-profile Health Training Center), Angola. Method: Report of experience of the use of community intervention projects in nursing. Results: Community intervention projects have contributed to the learning of students and to the promotion of health, citizenship and the empowerment of individuals and communities. Its implementation is in the fourth year, and 16 projects have already been developed in 2 distinct neighborhoods, and this year the intervention will cover a third. Conclusions: Nursing teaching should adopt strategies that lead the student not only in the path of professional autonomy, but, above all, in the empowerment of people and communities. Community intervention is undoubtedly important in this area.

Descriptors: Community Health Nursing; Health Education; Empowerment; Community Health Planning; Education in Nursing.

\section{RESUMO}

Objetivo: Relatar a implementação e resultados de projetos de intervenção comunitária utilizados como estratégia de ensino e desenvolvimento de pessoas e comunidades, na formação de enfermeiros especialistas em enfermagem de saúde comunitária, no Centro de Formação de Saúde Multiperfil, Angola. Método: Relato de experiência da utilização de projetos de intervenção comunitária em enfermagem. Resultados: Os projetos de intervenção comunitária contribuíram para a aprendizagem dos estudantes e para a promoção da saúde, cidadania e empoderamento de pessoas e comunidades. A sua implementação está no quarto ano, e já foram desenvolvidos 16 projetos em 2 bairros distintos, sendo que este ano a intervenção abrangerá um terceiro. Conclusões: $\mathrm{O}$ ensino em enfermagem deve adotar estratégias que conduzam o estudante não só no caminho da autonomia profissional mas, sobretudo, na capacitação das pessoas e comunidades.

Descritores: Enfermagem em Saúde Comunitária; Educação em Saúde; Empoderamento; Planejamento em Saúde Comunitária; Educação em Enfermagem.

\section{RESUMEN}

Objetivo: Informar de la implementación y resultados de proyectos de intervención comunitaria utilizados como estrategia de enseñanza y desarrollo de personas y comunidades, en la formación de enfermeros especialistas en enfermería de salud comunitaria, en el Centro de Formación de Salud Multiperfil, Angola. Método: Relato de experiencia de la utilización de proyectos de intervención comunitaria en enfermería. Resultados: Los proyectos de intervención comunitaria contribuyeron al aprendizaje de los estudiantes y a la promoción de salud, la ciudadanía y el empoderamiento de personas y comunidades. Su implementación está en el cuarto año, y ya se han desarrollado 16 proyectos en 2 barrios distintos, mientras que este año la intervención abarcará un tercero. Conclusiones: La enseñanza en enfermería debe adoptar estrategias que conduzcan al estudiante no sólo en el camino de la autonomía profesional, sino especialmente en la capacitación de las personas y comunidades. La intervención comunitaria es claramente importante en este ámbito.

Descriptores: Enfermería en Salud Comunitaria; Educación en Salud; Empoderamiento; Planificación en Salud Comunitaria; Educación en Enfermería.

\section{CORRESPONDING AUTHOR Elsy Alejandra de Oliveira Tavares E-mail: elsy.tavares@multiperfil.co.ao}




\section{INTRODUCTION}

Angola has a very young population, like most developing countries, and constitutes a challenge for the country's progress. There are asymmetries in the communities due to unequal opportunities in the whole territory, which causes internal migratory movements to the urban centers and overload in the available public services. The Angolan government has set a set of priorities aimed at promoting human, participatory and sustainable development. This recognizes the need to strengthen support to health education and research institutions, to assess the quality of training of health professionals and to monitor and evaluate the performance of health teams ${ }^{(1)}$. Responding to these goals, the Centro de Formação de Saúde Multiperfil (Multi-profile Health Training Center) in Luanda, Angola (CFS), has been developing since 2014 the Curso de Pós-Licenciatura de Especialização em Enfermagem de Saúde Comunitária (Post-Graduate Specialization Course in Community Health Nursing). This 2,900 hour course includes a community intervention internship component, where the health planning methodology is used to intervene directly in the community, empowering it, promoting citizenship and increasing context.

It is imperative to legitimize the role of the individual, groups and community in building environments conducive to individual and collective health and their social intervention clearly translates into a need that must be promoted and encouraged. It is essential to contribute to the empowerment of individuals, groups and communities so that they not only recognize the right to respond to their real health needs, but also consider their responsibility to participate and contribute to the construction of the same response. Every citizen should be able to recognize how much their behavior influences their health, those, and their surroundings.

The CFS, as a promoter of citizenship, emphasizes, in the training of specialist nurses, the promotion of citizenship in the community, that is, it contributes to progressively autonomous, responsible and participatory citizens in their health and life process. The student, through interaction with the community and through the exercise of his autonomy as a health professional, becomes a participatory subject, responsible for the pursuit of his learning and human growth, developed in the course of his academic training. In the construction of practical knowledge, it mobilizes criticalreflexive and creative thinking, so that the different contexts that this professional in training faces are opportunities for learning and restructuring at all times, and this is a continuous activity.

The nurse specialist in community health nursing, due to its proximity to the community, has the possibility of collaborating actively in the elaboration of health projects that promote the exercise of citizenship and empowerment. The participation of the nurse (student) in the community during the internship presupposes that the nurse develops the capacity to reflect on the practice, the ability to listen actively, and the ability to determine the needs of the population in health care. -2). It implies, therefore, to promote citizenship and empowerment through community intervention projects.

Thus, the present article aims to present an account of the experience of the CFS in the scope of the use of community intervention projects in nursing education, with a view to empowerment and citizenship and having as reference the Afaf Meleis Transitions Theory and the theoretical model of Nola Pender.

\section{OBJECTIVE}

To report the implementation and results of community intervention projects used as a teaching strategy and in the training of community nurse nursing specialists at the Centro de Formação de Saúde Multiperfil (Multi-profile Health Training Center) in Luanda, Angola.

\section{RESULTS}

\section{History of the implementation of community intervention projects}

The Angolan population remains vulnerable to health problems, which create an overload on the providers of this service and hinder access to primary health care, so this makes special training of nurses in this field a priority. Education is a fundamental element for the development of nations, and its role in the formation of citizens is undoubted; however, a consistent educational process, involving various sectors of society, is necessary for citizenship to be built and consolidated.

The CFS is, undoubtedly, a space where citizenship is developed. It recognizes the importance of teachers' attitudes and the importance of teaching in student training; recognizes the student as a citizen; and perceives citizenship as an active participation in society beyond the rights and duties of each. The involvement of the teacher in the construction of student citizenship occurs through the transmission of knowledge during the theoretical period and also by the educational practices planned and organized in the context of the internship. Teachers identify community intervention projects as a fundamental tool in the development of the exercise of citizenship, allowing better health and life conditions for the population.

The projects carried out in a training context allow the community health nursing student to contribute to the empowerment, empowerment and exercise of citizenship of the health of individuals, families, groups and communities and to collaborate in the achievement of the objectives of the Plano Nacional de Desenvolvimento Sanitário de Angola (National Health Development Plan of Angola) (2012-2025), in addition to the development of other competences recommended for this area of specialty and embodied in the study plan of the course, published in DR I Series no 37 of March 18, 2015.

\section{Strategies and partnerships}

The students $(\mathrm{N}=16), 9$ females and 7 males, with a mean age of 42.75 years, implemented community intervention projects in the 2014-2016 school years. In this way, and as a result of the assumptions mentioned above, each of them developed their actions in the areas of intervention emanating from the health diagnosis carried out in the Kapossoca community or by the needs identified and considered as priorities in the Plano Distrital de Desenvolvimento Sanitário da Samba, (Samba District Health Development Plan), 2013-2017 (Chart 1). These needs were confirmed during the preparatory visits to the Kapossoca and Camuxiba communities, as well as those responsible for the neighborhoods included in the intervention. The projects developed in the community were thus based on the promotion 
of health, citizenship and community empowerment and enabled the school (CFS) to develop as an intervening agent in these areas.

Empowerment, that is, the process of acquiring knowledge and developing skills that leads to the increase of power and control by the citizen, allows the participation and effective decision making in the responsible exercise of citizenship, by developing self-responsibility for health, as well as being responsible for the community in which it operates ${ }^{(2)}$. In reality, empowerment is based on citizen participation through strategies that empower individuals and communities to make decisions and defend their rights ${ }^{(2)}$.

The work developed with the community had its greatest emphasis in the area of health promotion, fully justified in the manifest needs of the communities. In the area of health promotion, centered essentially on educational health actions, the theoretical model of health promotion of Nola J. Pender ${ }^{(3)}$ was followed, since it provides a simple and clear structure in which nurses can perform individual or group care; allows planning, intervening and evaluating the actions that lead to health promotion; as well as three main points: individual characteristics and experiences, feelings and knowledge about the behavior to be achieved and desirable health promotion behavior ${ }^{(3)}$.

All the projects developed followed the methodological design of the health planning suggested in the reference work of Imperatori and Giraldes ${ }^{(4)}$ and met the ethical principles regarding data collection and treatment, namely confidentiality, anonymity and free and informed consent .

After surveying the needs of the community, the priorities for intervention based on the health problems revealed were of high magnitude, transcendence and vulnerability, and goals, indicators and targets were set. The major strategies for the development of community intervention projects consisted of health promotion/ education, in-service training of health professionals, project partners, conducting screening activities (blood pressure assessment, blood glucose assessment, data evaluation anthropometrics and plasmodium research) and in the establishment of partnerships, with the health entities of the place of implementation of the projects, with the residents' committee and its president, with neighborhood institutions and the National Institute of Public Health and Fight against AIDS. These initial activities have strengthened the relationship established between the school and the community.

Group health education sessions were held during the implementation of the projects and clarified the doubts presented by the participants during the health education sessions, using a participatory strategy, associated to several didactic resources. The technical terms were decoded into the popular language. The experience allowed us to know the peculiarities of the groups and to plan comprehensible and meaningful orientations for the population. After each health education and in-service training session, knowledge assessment questionnaires were applied, which allowed to verify if the proposed goals had been reached.

The concern with physical activity and the health benefits that this entails was demonstrated by walking, gymnastic exercises and a soccer game between a community team and another in the neighborhood where the projects were developed. In addition to the benefits to physical health, such activities provided the relationship between the community and students.

The exercise of citizenship also implies ecological awareness. In this sense and on the day of the environment, a campaign was carried out to clean the central area of the neighborhood - a space that is central to all the activities carried out in this context - and a tree planting in several places, making residents responsible for their care. This campaign, developed by the students in 2016, proved to be an asset in establishing a relationship of trust that proved to be fundamental to the school's approach to the community. Subsequently, other cleaning campaigns were carried out elsewhere in the neighborhood, as well as intra/extra-community spraying activities.

Screening activities were carried out at various locations in the Kapossoca neighborhoods in 2014 and Camuxiba in 2016, with the health fairs held in each of these years being highlighted with the collaboration of the various project partners. The fairs focused on screening, health education, delivery of disinfectants to water, delivery of condoms and leaflets related to the themes of the different projects, as well as administration of vaccines in accordance with the national vaccination plan for children and adults.

In-service training sessions were aimed at empowering Health Center professionals to improve the quality of care provided to people and to strengthen the demand for primary health care by the population.

The evaluation of the projects was based on the results of the questionnaires applied at the end of the health education and inservice training sessions. The data obtained from the evaluation of the questionnaires allowed to characterize the population that participated in the sessions, as well as to determine the level of knowledge after the session. In the analysis of the results, the descriptive statistic was used through the statistical program SPSS, version 21.

Chart 1 - Areas and titles of developed community intervention projects (2014-2016)

\begin{tabular}{|c|c|c|}
\hline Health promotion & Citizenship promotion & Empowerment promotion \\
\hline $\begin{array}{l}\text { 1. Healthy sexuality, happy teenagers" } \\
\text { 2. "Growing old healthy" } \\
\text { 3. "Eating well to grow up well" } \\
\text { 4. "Growing up healthy" } \\
\text { 5. "Promotion of oral health to the children } \\
\text { from the district of Kapossoca" } \\
\text { 6. "Live better without diabetes" } \\
\text { 7. "Live with life quality-HIV/AIDS } \\
\text { 8. "Take care of your Blood Pressure" } \\
\text { 9. "Better eating, better growing" } \\
\text { 10. "Tuberculosis, better to prevent" }\end{array}$ & $\begin{array}{l}\text { 1. "Safe children today, happy adults } \\
\text { tomorrow" } \\
\text { 2. "Living with no violence" } \\
\text { 3. "Camuxiba without Malaria" }\end{array}$ & $\begin{array}{l}\text { 1. "Living healthy and with quality of life" } \\
\text { 2. "Friend of life: alcoholism prevention" } \\
\text { 3. "Family planning, healthy family" }\end{array}$ \\
\hline
\end{tabular}




\section{The repercussion of the projects implemented}

According to the Ottawa Charter ${ }^{(5)}$, there are five key strategies for successful health promotion interventions: building healthy public policies, building health support settings, strengthening community action, developing personal skills and reorientation of health services. Health promotion emerges as a process that seeks to create conditions for people to increase their capacity to act on health determinants, giving individuals and the community the means to better manage their own health and developing strategies in decision-making processes. Health promotion and education reinforces both professional and client democracy and autonomy, culminating in a feeling of greater satisfaction and personal fulfillment for both. Promoting health therefore involves helping people to develop skills to make healthy choices through education and information so that they can exercise control over their health and contexts ${ }^{(6)}$. The individual is considered as the subject and agent of his own learning and responsible for his options. In the process of health education, and in order to increase the level of well-being and health of the target community of intervention, the students established a helping relationship, where they used listening, availability and attention to the Other, which created a climate of trust and respect.

Concerning the knowledge acquired during the health education sessions, it was verified that the majority of the participants answered correctly the questions asked in the questionnaires applied at the end of the sessions. The right and duty of populations to participate individually and collectively in the planning and delivery of their health care is of particular importance after the Alma-Ata Conference. Citizenship in health refers to the ability to exercise, in an informed and responsible manner, power/influence over their health status and the development of the health system and services ${ }^{(7)}$. Giving this power, especially in peace building contexts, is undoubtedly associated with capacitybuilding and the development of active citizen participation in the life of the community ${ }^{(8)}$. Taking such a commitment, as a student nurse, implies providing relevant information to help individuals, families and communities to increase health education, gain control over decisions that affect their health, and promote their effective participation in the care process. health gains ${ }^{(9)}$. The elaboration and implementation of community intervention projects have constituted themselves as contributory tools for the transformation of society, which aims at more conscious and participative citizens ${ }^{(2)}$. These projects, starting now with another class, are integrated into the teaching-learning context and allow the student to transfer knowledge learned in a theoretical context to the social context, with the aim of contributing to the promotion of citizenship in the community.

Students, when implementing intervention projects, help in the process of transformation and in the emancipation of the citizen, who is stimulated to reflect and learn, in a creative way, based on relational interaction, becoming an active participant in his life project and, consequently, health. This teaching-learning strategy has, therefore, an educational aspect in the promotion and prevention of health, to the community that will have at its disposal a set of information about the behaviors to adopt for a healthier life. In reality, the student, in the relationship he establishes with the individual, family and/or community, develops his role as educator, trainer and counselor, in order to positively facilitate the transitional process experienced by the person.

There was frequent participation of people from all sectors of the neighborhoods involved in the activities (minimum of 15 people in a health education session, under the "Camuxiba without malaria" project, and a maximum of 388 in the health fair). Citizen participation appears as an attitude of active citizenship, which demands a more humanized health care, with access to information and participation in decision making. Increased consumer rights, higher health care costs, and increased awareness of the fallibility of healthcare professionals have led citizens to become more actively involved in their health process ${ }^{(2)}$. The evolution of values in society increasingly recognizes man's free will and self-determination and calls for a more humanized nursing consciousness, with care centered on the individual, family and community ${ }^{(7)}$. Nursing students today consider the person to be responsible for their own life and health project, putting at their disposal a whole range of knowledge and mastery. In their health promotion exercise, they encouraged people and communities to gain control over their own health and thus contributed to their development and empowerment ${ }^{(10)}$.

In order to carry out the projects and as mentioned previously, the students were able to: establish partnerships with local and health entities that allowed the integration of students in the neighborhood and the dissemination of projects; provide the places to carry out the activities; and provide some necessary human resources, materials and equipment. Partnerships enable community empowerment and empowerment, respecting differences ${ }^{(4)}$. In this way, we worked as a team, which required the ability to interact with a group of people, articulating actions to achieve common goals, respecting different limits, values, beliefs and needs.

The great participation of citizens $(x=70)$ was observed in health education sessions with active methodologies, associated to screening activities and distribution of didactic material. Education in health emerges as a fundamental pillar of the development of citizenship, and education and information are important foundations for the empowerment of the citizen, allowing not only power, but also predisposition to participatory habits ${ }^{(2)}$. It is the duty of the citizen to inform him, to train himself, to respect and to promote his own health. In order for health education activities to achieve the desired goals, it is essential that the messages transmitted be understood and, subsequently, the acquired knowledge be acted upon ${ }^{(3)}$. This demanded attention from the student in the production of information, in order to guarantee an open, transparent and accessible communication to the population, considering that there are factors - such as communication, trust in the nurse, and limited possibility of participation - that influence participation in the care process and consequent exercise of citizenship.

In-service training in the development of projects has contributed to the qualification of professionals with regard to the humanization of health care. Intervening with the community and valuing health care implies valuing the client's rights, respect for their individuality, dignity, autonomy, and subjectivity. Since the person is the center of care, it is said that humanization is a central aspect of citizenship. It implies listening, respecting and preserving the dignity of people, investing in the quality of 
the professional-client relationship, creating environments that foster this relationship. Coordinated action for health through community-driven projects involves developing individual skills, creating health-friendly environments, and reorienting health services with a focus on health promotion and disease prevention, and it is critical that the community can understand the advantages of their involvement in health promotion activities ${ }^{(2)}$.

\section{FINAL CONSIDERATIONS}

As health, values and conceptions about health are cultural traits, many aspects come together to determine the health of individuals, families and communities. The multicultural reality of Angola provides the existence of myths and practices and behaviors that are not always healthy.

The training of specialist nurses in the CFS is part of the context of changes and challenges facing today's society, which is fundamental to the quality and rigor of training, but also respect for culture. In this context, the school and students are expected to participate in multi-professional teams, fostering synergies capable of overcoming difficulties and constructing projects. The formative course of students includes periods of theory in the CFS, where the exercise of citizenship is awakened, and periods of clinical practice, with stages in the community, along which they can extend this exercise to the population with whom they have established a partnership. The community intervention projects implemented allowed the promotion of health, citizenship and the empowerment of people and communities. The contribution of the students was reflected in an active citizenship of the population through counseling and information, risk prevention, early identification of the disease and reduction of complications in people with established disease.

Adding to the cognitive rationality the feelings, the language and the capacity to develop rational arguments about the actions, the student nurses developed behaviors based on the ethics and the morals, allowing a more effective and efficient action and more conscious of its responsibilities as citizens. With this pedagogical approach (community intervention project), students were able to cope with complexity and social and health unpredictability, in building not only an informed, conscious, participatory and responsible society for their health and their community, but also of citizens more aware of the power of their active, productive and conscious participation.

\section{REFERENCES}

1. Organização Mundial de Saúde - OMS. Estratégia de cooperação da OMS 2015-2019. Angola: Escritório Regional Africano; 2016.

2. Leite RB, Pontes CS, Pavão JF. Cidadania para a saúde. o papel do cidadão na promoção da saúde. Lisboa: Universidade Católica Editora; 2015.

3. Pender NJ. Health Promotion Model Manual [Internet]. Michigan: University of Michigan; 2011[cited 2017 Apr 23]. Available from: https://deepblue.lib.umich.edu/bitstream/handle/2027.42/85350/HEALTH_PROMOTION_MANUAL_Rev_5-2011.pdf

4. Imperatori E, Giraldes MR. Metodologia do planeamento da saúde: manual para uso em serviços centrais, regionais e locais. Lisboa: Escola Nacional de Saúde Pública; 1993.

5. Conferência Internacional sobre Promoção da Saúde. A promoção da saúde: a carta de Ottawa [Internet]. 1986 [cited 2017 Apr 23]. Available from: http://www.iasaude.pt/index.php/informacao-documentacao/promocao-da-saude/152-carta-de-ottawa

6. Silva S. Políticas e práticas de promoção de hábitos e estilos de vida saudáveis nas crianças e jovens do Concelho de Torres Vedras. Rev Port Saúde Pública [Internet]. 2013[cited 2017 Apr 23];31(1):84-94. Available from: http://www.scielo.mec.pt/pdf/rpsp/v31n1/ v31n1a09.pdf

7. Gonçalves C, Ramos V. Cidadania e saúde um caminho a percorrer. Lisboa: Escola Nacional de Saúde Pública; 2010.

8. Borges M, Maschietto H. Cidadania e empoderamento local em contextos de consolidação de paz. Rev Crit Cienc Sociais [Internet]. 2014[cited 2017 Apr 23];105:65-84. Available from: https://journals.openedition.org/rccs/pdf/5800

9. Martins P, Cotta R, Siqueira-Batista R, Mendes F, Frachescinni S, Priore S, et al. Democracia e empoderamento no contexto da promoção da saúde: possibilidades e desafios apresentados ao programa de saúde da família. Physis [Internet]. 2010 [cited 2017 Apr 23];19(3):679-94. Available from: http://www.scielo.br/pdf/physis/v19n3/a07v19n3.pdf

10. Apóstolo JL. Envelhecimento Saúde e Cidadania. Rev Enf Referência [Internet]. 2013[cited 2017 Apr 23];9:205-8. Available from: http://www.scielo.mec.pt/pdf/ref/vserllIn9/serllln9a21.pdf 